\title{
Maintaining the SDGs Target During Pandemic COVID 19:
}

\author{
Indonesian Case
}

\author{
Asti Amelia Novita* \\ Public Administration Department, Faculty of Administrative Science \\ Universitas Brawijaya \\ Malang, Indonesia \\ *asti@ub.ac.id
}

\begin{abstract}
Based on the 2020 Sustainable Development Report, the COVID-19 pandemic has harmed almost all SDGs goals, especially related to reducing poverty, hunger, achieving health and well-being and ensuring a layer of work and economic growth. For Indonesia, the COVD-19 pandemic not only affects Indonesia's economic growth, but also has an impact on the achievement of the Sustainable Development Goals (TPB/SDGs). The spread of this virus has forced the Indonesian government to make strategic adjustments and efforts to achieve the SDGs target. By using the literature review method, this paper aims to examine the efforts of the Indonesian government in maintaining the stability of achieving the 17 SDGs points. At present, the Ministry of National Development Planning is preparing a draft National Action Plan 2020-2024 which includes actions to achieve the goals of the SDGs after the COVID-19 pandemic. The Ministry of National Development Planning has also prepared solutions as scenarios in the short, medium and long term for the implementation of the SDGs. However, a more comprehensive scenario is needed to maintain the achievement of the SDGs targets in Indonesia.
\end{abstract}

Keywords—sustainable development, SDGs target, COVID-19, pandemic

\section{INTRODUCTION}

In late 2019, the coronavirus outbreak (later called COVID19) spread rapidly globally, including Indonesia. There has been no practical solution to solve the pandemic, which has been going on for more than one year. The number of patients infected with COVID-19 in Indonesia continues to grow even though several policies have been issued. Based on data from the COVID-19 Handling Task Force as of January 18, 2021, there were an additional 9,086 new cases of COVID-19 in the last 24 hours [1]. This increase has resulted in the number of patients infected with COVID-19 in Indonesia now reaching 917,015 people, starting from the announcement of the first case of COVID-19 on March 2, 2020 (Figure 1).

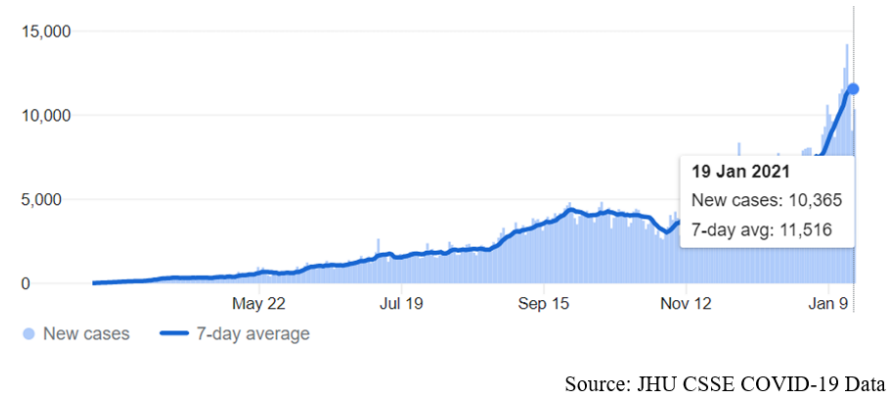

Fig. 1. Statistic of Covid Cases in Indonesia all time.

The outbreak of a pandemic in Indonesia has affected all aspects of people's lives. In terms of the economy, the Covid19 pandemic has caused an increase in unemployment. Many people have complained, and their activities have stopped due to the Covid-19 pandemic. In Indonesia, the number of unemployed people increased by 3.7 million people due to the pandemic [2]. The increasing number in unemployment indicates the government's failure to achieve sustainable development goals, namely increasing public welfare and reducing poverty.

Currently, the government has provided a policy response implemented in four stages, namely, strengthening health facilities, protecting vulnerable groups of people and the business world, reducing pressure on the financial sector, and implementing post-coronavirus recovery programs. The government also already has a post-COVID-19 development plan by making COVID-19 a transformation or radical change. Four aspects will transform which are acceleration, industrial recovery, tourism and investment, national health system reform, social protection system reform, and disaster resilience system reform.

\section{RESEARCH METHODS}

This study uses a qualitative descriptive approach with secondary data analysis. Secondary data analysis is a research strategy that utilizes existing quantitative or qualitative data to 
find new problems or tests previous research results. Secondary data analysis includes two main processes: collecting data and analyzing the amount of information obtained [3]. There are four stages in carrying out secondary data analysis, namely identifying information sources, collecting available data, normalizing data if needed, and analyzing data [4]. Secondary data sources are obtained from data and official reports from government agencies, official data, and reports from international institutions, articles, and reputable journals.

\section{INDONESIAN TARGET ON SDGS AND PANDEMIC}

The Sustainable Development Goals, better known as the Sustainable Development Goals (SDGs), are an urgent call for action to end poverty while improving health and education, reducing inequality, and tackling climate change. The Sustainable Development Goals (SDGs) were declared on 25 September 2015 at the United Nations Headquarters in New York by 193 countries as a commitment to the Global Development Agenda. The Sustainable Development Goals are a continuation and refinement of the Millennium Development Goals (MDGs) implemented during the $2000-2015$ period. The SDGs refine the previous Global Development Agenda by emphasizing a development commitment that not only focuses on human development but also environmentally friendly on economic development and environmental development. SDGs place humans as central actors and enjoyers of development results aimed at human welfare or human wellbeing.

Indonesia's ranking in the 2020 SDG Index has increased, from 102 in 2019 to 101 out of 166 countries [5]. This index measures performance based on progress towards achieving the 17 goals in the SDGs. Despite the improvement, there is still much work to be done. In the report 'The Sustainable Development Goals and Covid-19', 10 out of 17 SDGs in Indonesia have improved where there is stagnation for goals 5 (Gender Equality), 11 (Sustainable Cities and Communities), 14 (Marine Ecosystems), 15 (Ecosystems Mainland), and 17 (Partnerships to Achieve Goals). Apart from positive developments in certain areas, Indonesia still faces challenges in terms of goals 2 (No Hunger), 3 (Healthy and Prosperous Life), 6 (Clean Water and Proper Sanitation), 9 (Industry, Innovation, and Infrastructure), 10 (Reducing Gap), 15 (Land Ecosystem), and 17 (Partnerships to Achieve Goals) [6].
However, the escalation of the COVID-19 pandemic has had a significant impact on achieving the 2030 sustainable development agenda, particularly for Indonesia. During the COVID-19 pandemic, there was a decline in welfare in all income groups characterized by a decrease in average consumption/capita throughout the decile, especially among people below the poverty line $(10.86 \%)$ and the poor and vulnerable $(30.77 \%)$ [7]. The lockdown policy to overcome the pandemic has resulted in decreased food access. If the transportation system and food logistics are disrupted due to the lockdown policy, the number of poor increases, the increase in layoffs will result in decreased access to food. In general, the COVID-19 pandemic impacted economic activity, decreased people's purchasing power, and limited transportation and logistics.

\section{INDONESIAN EFFORTS ON MAINTAINING SDGS TARGET DURING AND POST PANDEMIC}

Currently, the government has provided a policy response implemented in four stages, namely, strengthening health facilities, protecting vulnerable groups of people and the business world, reducing pressure on the financial sector, and implementing post-coronavirus recovery programs. The government also already has a post-COVID-19 development plan by making covid-19 a transformation or radical change. There are four central policies to achieve post-COVID-19 sustainable development goals: economic policies, social policies, environmental policies, and legal and governance policies.

Economic policies in response to COVID-19 go through four stages: strengthening health facilities, protecting vulnerable groups of people and the business world, reducing pressure on the financial sector, and post-COVID-19 economic recovery program (table 1 ). Besides, in 2020, the government will carry out a fiscal stimulus as a counter-cyclical policy effort to minimize the impact of the COVID-19 pandemic on the economy and society. The 2020 fiscal stimulus for handling COVID-19 was 669.7 trillion rupiahs, with details of 87.55 trillion rupiahs for health, 123.46 trillion rupiahs for MSMEs, 203.90 trillion rupiahs for social protection, 37.7 trillion rupiahs for corporate financing, 179.48 trillion rupiahs for business incentives, and 38.24 trillion rupiahs for sectoral and local government [8].

TABLE I. FOUR STAGES IN RESPONSE COVID-19

\begin{tabular}{|c|c|c|c|}
\hline $\begin{array}{c}\text { Stage 1 } \\
\text { Strengthening Health Facilities }\end{array}$ & $\begin{array}{c}\text { Stage 2 } \\
\text { Protecting Vulnerable Community } \\
\text { Groups and the Business World }\end{array}$ & $\begin{array}{c}\text { Stage } 3 \\
\text { Reducing Financial } \\
\text { Sector Pressure }\end{array}$ & $\begin{array}{c}\text { Stage } 4 \\
\text { Post-COVID Economic } \\
\text { Recovery Program }\end{array}$ \\
\hline $\begin{array}{l}\text { - Increase in healthy behavior and social } \\
\text { distancing } \\
\text { - Fulfillment of laboratory capacity (reagents, } \\
\text { test equipment, and laboratory facilities) } \\
\text { - Patient handling (PPE, medical devices, health } \\
\text { facilities, and infrastructure) }\end{array}$ & $\begin{array}{l}\text { - Expansion of social assistance, free } \\
\text { electricity, and pre-employment cards. } \\
\text { - Tax relief for businesses and workers, } \\
\text { and credit relief for businesses } \\
\text { - Economic recovery program for } \\
\text { businesses and MSMEs }\end{array}$ & $\begin{array}{l}\text { - Monetary and financial } \\
\text { stimulus } \\
\text { - Liquidity assistance to } \\
\text { the financial sector } \\
\text { - Interest rate reduction }\end{array}$ & $\begin{array}{l}\text { The } 2021 \text { Government Work } \\
\text { Plan provides a direction for } \\
\text { economic recovery to pursue } \\
\text { the targets set in the 2020- } \\
2024 \quad \text { Medium-Term } \\
\text { Development Plan }\end{array}$ \\
\hline
\end{tabular}

Social policies in handling COVID-19 include social protection programs such as the basic food program, family hope program, electricity assistance, pre-employment card programs, special social assistance for DKI Jakarta, special 
social assistance for JaBoDeTaBek (Jakarta, Bogor, Depok, Tanggerang Bekasi), cash social assistance outside of JaBoDeTaBek, as well as direct cash assistance for village funds. National health system reforms are also carried out to strengthen the health system in facing pandemics and public health emergencies of international concern (PHEIC), postCOVID-19 recovery and control of health problems, strengthening promotive and preventive, and increasing government health budgets.

Other social policies are related to education after the COVID-19 pandemic, namely accelerating the distribution of quality education throughout the region, improving primary to secondary education services by paying special attention to poor and vulnerable groups of people, fulfilling teachers, education personnel, improving quality of teaching and learning and creating digital-based learning innovations.

Post-COVID-19 environmental policies include anticipating the impact of medical waste handling COVID-19 and strengthening disaster resilience systems. The main problem related to the disaster system detected due to the emergence of the COVID-19 pandemic is the limited attention to handling non-natural disasters, including health disasters. Besides, the impact of non-natural disasters is multi-aspect in nature, so that it requires an integrated strategy in national and regional development. Meanwhile, urban residents and growth centers have a high risk of disaster, while weak disaster mitigation can provide enormous potential for economic loss. Because of that, the focus of strengthening the disaster resilience system is divided into two, namely increasing predisaster preparedness and strengthening the emergency response operating system (Table 2 ).

TABLE II. STRENGTHENING THE DISASTER RESILIENCE SySTEM (FocUs ON 2021)

\begin{tabular}{|c|c|}
\hline $\begin{array}{c}\text { Increased preparedness in pre- } \\
\text { disaster times }\end{array}$ & $\begin{array}{l}\text { Strengthening the emergency } \\
\text { response operating system }\end{array}$ \\
\hline $\begin{array}{l}\text { 1. Strengthening community- } \\
\text { based disaster management } \\
\text { through increased } \\
\text { understanding of disaster risk } \\
\text { based on science, } \\
\text { technology, local wisdom to } \\
\text { the community, and } \\
\text { apparatuses (disaster resilient } \\
\text { village) }\end{array}$ & $\begin{array}{l}\text { 1. Strengthening integrated and } \\
\text { multisector crisis management } \\
\text { through the preparation of } \\
\text { regulations for the quick } \\
\text { activation of emergency } \\
\text { response operations centers and } \\
\text { the application of integrating and } \\
\text { mainstreaming disaster risk } \\
\text { reduction in the regions }\end{array}$ \\
\hline $\begin{array}{l}\text { 2. Increase investment in } \\
\text { disaster risk reduction, } \\
\text { especially for the threat of } \\
\text { health disasters such as } \\
\text { increasing PPE and hospitals' } \\
\text { capacity. }\end{array}$ & $\begin{array}{l}\text { 2. Strengthening an integrated } \\
\text { disaster data system and one } \\
\text { reference as a joint reference in } \\
\text { implementing } \\
\text { interventions quickly } r \text { and } \\
\text { precisely }\end{array}$ \\
\hline $\begin{array}{l}\text { 3. Develop contingency plans, } \\
\text { operational plans, and other } \\
\text { strategies as standard } \\
\text { operating procedures for } \\
\text { joint handling of disasters in } \\
\text { affected areas such as } \\
\text { investment centers, industry, } \\
\text { tourism, and food production } \\
\text { areas. }\end{array}$ & $\begin{array}{l}\text { 3. Strengthen the logistics system } \\
\text { (especially food) and social } \\
\text { safety nets to reduce the socio- } \\
\text { economic impact on society } \\
\text { during crisis times and help } \\
\text { accelerate recovery for a better } \\
\text { condition. }\end{array}$ \\
\hline
\end{tabular}

Legal policies are related to the consequences of large-scale social restrictions and civil emergencies and their impact on the law. Meanwhile, governance policies related to public services continue to run with the implementation of cybersecurity for government organizations. The PSBB or civil emergency policy impacts the implementation of legal and judicial processes by limiting/closing public service facilities starting from the stage of investigations, trials, and community facilities. The minister of Law and Defense's policy to stop detention facilities in detention centers and prisons require strategic steps and changes to the criminal justice system's business process mechanism. Policies that need to be issued are related to changes in handling cases at trial, anticipating criminal acts, eliminating detention in detention/prisons (overcrowded vs. social distancing, and controlling prison visits.

The government policy related to public service governance is online service activities that vulnerable to cybersecurity issues. Therefore, policies related to public services must ensure the security of systems that can be accessed remotely due to work from home activities. The socialization of software use also supports this policy during work from home activities.

\section{CONCLUSIONS}

The pandemic conditions that have persisted until now have hampered almost all of Indonesia's sustainable development goals. Several government strategies to anticipate the adverse effects of COVID-19 on achieving the SDGs goals have been taken seriously. Government policies related to handling COVID-19 include four main policies, namely social, economic, legal, and governance policies as well as environmental policies. However, the effectiveness of the policies and programs raised still needs to be further monitored and studied. Furthermore, this government policy needs to involve many parties to ensure harmony between policy and implementation.

\section{REFERENCES}

[1] N.R. Aditya, UPDATE 18 Januari: 9.086 Kasus Baru Covid-19 Tersebar di 32 Provinsi, DKI Terbanyak, 2021. [Online] Retrieved from: https://nasional.kompas.com/read/2021/01/18/16410981/update-18januari-9086-kasus-baru-covid-19-tersebar-di-32-provinsi-dki?page=all

[2] M. Fauzia, Akibat Covid-19, Jumlah Pengangguran RI Bertambah 3,7 Juta, 2020. [Online] Retrieved from: https://money.kompas.com/read/2020/07/28/144900726/akibat-covid19-jumlah-pengangguran-ri-bertambah-3-7-juta.

[3] M.K. McCaston, "Tips for collecting, reviewing, and analyzing secondary data," HLS Advisor, vol. 27, pp. 1-9, 2005.

[4] B. Kolb, Conducting secondary research. Sage secondary data analysis, 2012, p. 111-128

[5] Gatra.com, Peringkat Indeks SDGs 2020 di Indonesia Meningkat, 2020. [Online] Retrieved from: <https://www.gatra.com/detail/news/485592/ekonomi/peringkat-indekssdgs-2020-di-indonesia-meningkat> 
[6] J. Sachs, G. Schmidt-Traub, C. Kroll, G. Lafortune, G. Fuller, and F. Woelm, The sustainable development goals and COVID-19. Sustainable development report, 2020.

[7] Kementerian Perencanaan Pembangunan Nasional/ Badan Perencanaan Pembangunan Nasional, Peta Jalan SDGs Indonesia Menuju 2030 Jakarta: Kementerian PPN/Bappenas, 2020.
[8] A. Rudiyanto, Pengaruh COVID-19 terhadap Tujuan Pembangunan Berkelanjutan, 2020. [Online] Retrieved from: https://kkp.go.id/ancomponent/media/upload-gambar-pendukung/DitJaskel/publikasimateri-2/SDGs-Talks-Menjaga-

Momentum/20200506\%20Final\%20Paparan\%20Deputi\%20KSDA\%20 SDG\%20IPB\%20-\%20sec.pdf 